\title{
THE REFORMULATION OF PUBLIC PROTECTION LAW
}

\author{
Pranata Andi Yudha \\ Postgraduate School, University of Airlangga, Indonesia \\ E-mail: andisiboro7206@gmail.com
}

\begin{abstract}
In order to maintain and implement the Kamtibmas (The Order of Public Protection) in this dynamical society movement, there must be a strategy to intercept crime within several attempts to minimize them. This study uses descriptive qualitative to analyze the data. The result of study states that: a) in practical, there are several factors that affect regulation of public protection role, one of them is the lawless situation for Linmas (Public Protection) as part of Kamtrantibnas personnel and the analysis of social empowerment to help intercepting the crimes; b) The regulation that order about the role of public protection to intercept crimes in Klojen sub-district, there are three phases which are illumination to the officers whereas the importance of public protector to intercept crimes among society, increasing the public protector personnel capacity and granting their authority; and c) several factors and obstacles that affect the reformulation of public protection regulation to help the Polri's duty intercepting crimes are: the limited budget provided by City government which is monthly Rp. 150.000 for each personnel, limited personnel option which still uses Karang Taruna youth participation as its finest personnel, this Bhabinkamtibnas assist is not enough because of another activity such as Pam, revising the procedures of local safeguarding by adding Linmas authority which most hamlet tend not to do as well.
\end{abstract}

\section{KEY WORDS}

Public protection, reformulation, intercept crimes, public service.

Geographically and economically, Klojen sub-district possessed a very strategically position. Geographically, the sub district is in the middle of other four sub district jurisdiction which is Lowokwaru, Sukun, Kedungkandang, and Blimbing sub-districts. Klojen becomes the centre of governance gathering and also economic centre for other four sub districts. Not only in internal region, the sub district also contributes to another regions such as Pasuruan region, Batu municipality, and Malang region. The busy economic traffic in this place invites many criminals to commit their action in this field. Based on Klojen sector police data of 2016, it shows unbalanced number of crimes and the case resolutions occurred during that year. The ability of officers to investigate the crimes is still under $10 \%$ even after the improvement of bureaucracy reformation of Polri internal structure, the reformation also affects Klojen Malang resort police as well. This revised version of reformation creates another personnel and authority addition. Meanwhile, the working culture of them is reformed by using working target system and Working Performance System known as SMK of Polri's personnel.

\section{METHODS OF RESEARCH}

The research uses legal research type as a descriptive approach to qualitative analysis, whereas the form of a normative juridical study that describes the observations of the role of the Linmas in helping the police to prevent crime. Next phase is to draw legal principles in the formulation of norms that will become references / input in Regional Regulation Draft on the Role of Satlinmas in crime interception in the City of Malang, based on the catering of philosophical, juridical and sociological facts through the study of literature namely reviewing the material in the form of laws and research results, the results of studies and other references as primary data and secondary data available. 
The data analysis method used in this study is a descriptive analysis model. The stages of the descriptive analysis model in this study consisted of: data condensation, data presentation, drawing conclusions and verification.

\section{DISCUSSION OF RESULTS}

The Regulation of Public Protection Role to Intercept Crime in Public Area. Technically, the consolidation of public protection attempts by Klojen resort police is by mandating each urban village of Klojen sub-district to revise the Code of Conduct order, Bhabinkamtibnas may assist the head of Neighborhood and Hamlet in process. The revision implementation is meant to consolidate the role and authorities of personnel in that area. If the members of public protector come from elders which has no maximum strength anymore, additional personnel may be added as functional duty or implementing structural function which is already stated in that revised version of Code of Conduct. First, there must be a mass illumination about the importance of public protection as part of neighborhood caring, it could be done by socialization within the head of civil service police of Malang city; socialization within head of Klojen sub-district about utilization of linms or other communities; socialization within head of urban village and hamlet. Second, it is about the training of crime interception procedure in Dodikjur Malang. Third, the assistance of Bhabinkamtibnas to help the head of Hamlet and Neighborhood to revise the code of conduct, the revised version must contain authority granting about intercepting crime.

Then, it is about the society participation in order to assist the officers to intercept the crimes. There are several phases in this stage. First, the personnel must be able to pursue people about law awareness and importance for them. the role of linmas, based on the result of study by Kepala Kesatuan Bangsa Politik dan Perlindungan Masyarakat, it states that the public protection service is a mandatory that becomes absolute authority for Province, region, and city government which are regulated on Law number 32 of 2004 about Regional Government specifically at article 13 and 14 act 1 . Thus, the public protection must be daily improved and maintained, especially to assist government in improving social service, natural disaster, and maintain the daily public order in the name of defend country campaign. There are several phases to gain awareness of society principality: humanity, it is fundamental as the form of society is human itself. In practical action, the personnel must perform greeting, regards, and smile to show attitudes toward people; dedicated, it is meant to serve the society in whatever term to serve and protect people at ultimate cost. The personnel of Linmas must have total working performance to serve the society, discipline, it means that the personnel must take firm action in decision making process. Eventually, the personnel must follow the law as their ultimate guidance in action.

Second, it is the increasing capacity of the personnel. The formulation of personnel may be added by recruiting local people to become the member of Satlinmas in Nagara/Village/Urban Village by Nagari representation/ head of village/urban village. The candidate must meet the requirement to assist the personnel on the field. Increasing personnel capacity needs to follow andragodi principles especially in training process. Training or workshopping process is meant to make ready the candidates in carrying their future duty. Thus, the andragodi principles will suit the requirement. In order to reveal the weakness and strength of each individual, there must be sharing evaluation phase to achieve positive attitude effect. It is a professional attitude that will be required to enforce and empower the law as protector of people.

Third, it is granting the authority. The authority granting could be performed in safeguarding action of the order and safety of the people which are: watching over the unusual activity of some people (intelligence function); the strong community of safeguarding will be able to detect larger and bigger crime such as terrorism movement or another disintegration movement, moreover to the perverted doctrine. The watch over action must be continuously maintained to serve the safeguard of people, the personnel must also guard the neighborhood from social discrimination such as prostitution, littering, and destructing public stuff. Another bad behavior of society is when the husband had an affair to some widow of 
another women ; they must be able to distribute the fundamental need to society; they could also help in election process and regional election level. The principles followed in granting authority process is the administration which is cooperating with other related institution and to the people itself.

Some targets of efforts to prevent crime in the context of maintaining kamtibmas consist of first, adherence to the rules by both community protection officers and the general public. Obedience to the rules is not free from rule awareness, and good rule awareness is obedience to the rules, and unconscious good rules are disobedience. Obedience itself can be divided into three types, including: Compliance which is compliance, that is if someone obeys a rule, just because he is afraid of being sanctioned. Weakness of this type of obedience, because it requires continuous supervision; Obedience that is identification, that is if someone obeys a rule, just because he is afraid that his good relationship with the other party is damaged; Internalization, which is if someone obeys a rule, truly feels that the rule is in accordance with the intrinsic values adopted. The strictness of the rules is essentially the loyalty that someone has as the subject of the rules of the rules of the rules which are manifested in the form of real behavior. While the awareness of the rules of society is something that is still abstract which has not been realized in the form of real behavior to fulfill the will of the rules themselves. Many of the people who have actually been aware of the importance of rules and respect for rules as rules that need to be obeyed, whether due to the instinct or rational urge. But in fact, this awareness is not realized in everyday life or in real practice. Secondly, the implementation of national and local development processes in the Klojen District. The creation of kamtibmas is expected to facilitate the development process both nationally and locally in Klojen District. Klojen Subdistrict is a sub-district that is considered as the center of government of Malang City, so there are several important buildings such as Malang City Hall building, DPRD building, Merdeka Square, Tugu Square, Mayor's Office and Malang Regent, and others. Institutions other than the Village Head, RW Management and RT management are the Village Community Empowerment Institution or abbreviated as LPMK assisted by Community Empowerment Cadres or abbreviated as KPM. In addition, there are 135,179 people in Klojen (2017) Subdistrict, which is a combination of 31,864 households. The profession of the population is generally dominant as traders, transporters, civil servants, and industrial workers. Approximately 37,000 (thirty seven thousand) residents only graduated from high school or equivalent. The total number of Linmas members as a whole is around 754 officers to occupy around 256 patrol posts. Related to this, it is necessary to prevent crime in the context of maintaining social security.

Third, the safety guarantee from the personnel to implement city within low crime environment. The personnel are known as civil apparatus to help people in their neighborhood. Thus, the idea of safety and security will be achieved. Aside from the duty and role of satlinmas above, it has another duty to safeguard the election process, it is stated in Home Affair Ministry regulation number 10 of 2009 and the KPU regulation number 3 of 2015 , it states that the power of satlinmas to help securing and ordering while the election process is on going, it is meant that satlinmas must help safeguarding the election setting. Satlinmas is an organization formed by the Nagari / Village / Kelurahan Government and consists of members of the community who are prepared and equipped with the knowledge and skills to carry out disaster management activities to reduce and minimize the consequences of disasters, and participate in maintaining security, peace and public order, and social activities. Fourth, it is the development of local people skill in order to maintain the safety of their neighborhood and intercept the upcoming crime which will threaten people. The guide lining process of linmas as server of people is trained by civil service police of republic of Indonesia (known as Satpol PP) since 2004. It is stated in law number 23 of 2014 about regional government which states that it is the mandatory of province/regional/city to maintain the safety of its people. The contribution of the society is very important in maintaining the order of public protection; the collective movement from both personnel and society determine the implementation of crime interception. It is mostly not a new concept where people help officers to make safe their neighborhood, it is the very own duty of the inner society to maintain their safety before the modern concept of police was invented. 
The Factors Affecting Public Protection Role Regulation. Technically, there are internal and external factors that affect the regulation about public protection. The external factors come from several sectors. First, it is the program's budget, it is very limited that the city governance only provide monthly Rp. 150.00 each personnel. Moreover, the financing process that come from CSR is still on low average, it is as a result of inactive action from Hamlet head to pursue the CSR owner to increase the budget. Second, it is the human resource of personnel. According to the legal letter number 340/2 1/35.73.500/2018 about the list of personnel members of 2018, it states that the Klojen sub-districts possessed 418 human resources which are spread among 11 urban villages. In the other hand, the human resource is considered as an obstacle in public service. The recruitment process is crucial when the personnel got limited option for the personnel which, at the end, still uses Karang Taruna youth participation. In one hand, the participation of Bhabinkamtibnas is still in low average as they are mostly busy on Pam program. Third, it is the order of code of condust. Mainly, there are several steps which are; the head of hamlet and neighborhood, babinsa, bhabinkamtibnas, and local people must attend the conducting process including the SCR stakeholder; the participants must gather the type of crime that mostly occur in their area; decide the cleaning schedule for each member; another is structural and functional system of security for linmas; regulate the moral and social sanction; the substance or the crime material; and sending the documents to Polri office for next level of judgement; determine the CSR stakeholder in security department from company. From those steps, not all urban villages of Klonjen sub district has proposed their code of conduct.

Meanwhile, the internal factor could come from some activities. First, it is the environment situation. Barnest and teeters shows several steps to intercept crime which are the awareness of upcoming fundamental need that will rise the social and economical pressure, these two will trigger people to commit crimes to solve the problem; and focusing the watch over individuals who have most potential to commit crimes; the committed crimes would able to come from psychological and biological factors of the social and economical lankness that would lead to harmony in forming and committing crimes. From the opinion of Barnest and Teeters above, we could assume that the economical and social situation must be improved to make people not to commit crimes and intercept it automatically. Meanwhile, the biological and psychological factors are merely secondary factor ${ }^{2}$. Maslow ${ }^{3}$ stated that humans will pursue their need ranging from basic into higher need (self actualisation). Second, it is the pattern of handling the nature of vulnerability in the general environment. The crimes are still vulnerable in our environment, the crimes has no schedule to be committed nor fear, the crimes is freely committed in Malang city both urban or rural area. As the icon of educational and tourism city object, the street crime and natural disaster are still haunting both local resident and the tourist who make visit to the city, meanwhile, Malang road become very rush as it is the only way to go on southern part of east java province. there are many factors that cause it, one of it is the development of life aspects of Malang city.the development of technology of communication and information has developed the life aspect of local residence as a result of internal condition, it is also as a result of regional, national, and even global movement. In order to intercept the negative change in bhabinkamtibnas, the police officers must be quick, total, and loyal in overcoming arising issues or even intercept the upcoming problem before it grows into major problem.

Third, it is the society support in public area. There are several things that people may execute to achieve bhabinkamtibnas; the religious and social elders must continuously inform the personnel about the current situation of bhabinkamtibnas on their neighborhood. Reviving the old security patrolling system of Siskamling to intercept the crimes, reviving the Sadarkum program on each level of society, the society must have scheduled meeting with police officers to predict the upcoming issue and how to handle it, the meeting process must be achieved in homogen perception instead of doing anarchy that will result on a new issue, the society must not be easily deceived with hoax, but they must be able to claim the anger or any other negative impact from the hoax. Fourth, it is the support from mayor of Malang city; the mayor only supports the Linmas by providing them a uniform and convinces the personnel to be neutral during the election process. The participation of mayor city is far from 
ideal as it does only focus on the upcoming regional election in 2018 instead of the safety and security of its people. The fifth, it is the support from police of republic of Indonesia. Sixth, synergy and coordination function. Basically, Linmas may perform their field duty on its maximum effort if only the society would support them and their system of procedures is well maintained.

\section{CONCLUSION AND SUGGESTIONS}

Based on the analysis and discussion of the study above, there are three conclusions within the research. First, practically, there are several factors that affect the authority of people protection formula, one of the factor is the lawless condition that does not regulate the role of Linmas and their procedures in intercepting the crime in order to maintain Bhabinkamtibnas and the analysis of society protection regulation empowerment in intercepting crimes. Second, about the regulation of people protection to intercept crimes in Klojen sub district, there are three phases of it which are the awareness campaign to the personnel about the importance of people protection to intercept crimes, the increasing capacity of the personnel, and authority granting. Third, there are several factors and obstacles that affect reformulation of people protection regulation to assist Polri in intercepting crimes, they are the limited budget where the city government only provide the program within monthly fee of Rp.150.000 for each personnel, in-optimum recruitment process as a result of limited option of the candidates that mostly picked up from Karang Taruna youth members, the minimum contribution from Bhabinkamtibnas who are mainly busy with Pam program, the revision of Code of Conduct that must grant the authority for Linmas, and most of the Hamlet still do not provide a proper Code of Conduct.

There are several suggestions, as follow:

- There must be an increasing number of Linmas members empowerment to support them in intercepting criminal action in Klonjen sub-district;

- The reformulation of people protection regulation should be increased as stated in the form of Regional Law of Ministry of Home Affairs Law number 84 of 2014 about Society Protection Implementation.

\section{REFERENCES}

1. Ali, M. (2008). Kejahatan Korporasi Kajian Relevansi Sanksi Tindakan Bagi Penanggulangan Kejahatan Korporasi, Arti Bumi Intaran. Yogyakarta.

2. Ancel, M. (1965). Social Deffence: A Modern Approach to Criminal Problems. London: Rautlege.

3. Arief, B. N. (2013). Kapita Selekta Hukum Pidana. Bandung: Citra Aditya.

4. Atmasasmita, R. (1993). Kapita Selekta Kriminologi. Bandung: Armico.

5. Bemmelen, J. v. (1984). Hukum Pidana I - hukum Pidana Materiil Bagian Umum. Bandung: Binacipta.

6. Budiman, A. N. (2004). Prinsip-Prinsip Sistem Informasi Manajemen terjemahan (Principles of management Information System: George M Scott. Jakarta: Raja Grafindo Persada.

7. Gaol, J. L. (2008). Sistem Informasi Manajemen Pemahaman dan Aplikasi. Jakarta: PT Grasindo.

8. Hamzah, A. (1979). Sistem Pidana dan Pemidanaan dari Retribusi ke Reformasi. Bandung: Alumni.

9. Hasibuan, D. H. (t.thn.). Reformulasi Kebijakan Deradikalisasi Mantan Narapidana Terorisme Dalam Upaya Penanggulangan Tindak Pidana Terorisme di Indonesia. Desertasi.

10. Hoefnagels, G. P. (1973). The Other Side of Criminology: An invertion of the Concept of Crime. Holand.

11. Sahetapy, J.E.. (1979). Ancaman Pidana Mati terhadap Pembunuhan Berencana. Bandung: Alumni. 
12. Kartanegara, S. (t.thn.). Hukum Pidana Bagian Satu. Bandung: balai Lektur Mahasiswa.

13. Laudon, K. C., \& Laudon, J. P. (2007). Sistem Infornasi Manajemen Edisi Kesepuluh Buku 1 terjemahan: Chriswan Sungkono dan Machmudin Eka P. Jakarta: Salemba Empat.

14. Miles, M. B., \& Huberman, A. M. (2007). Analisis Data Kualitatif, Buku Sumber tentang Metode-metode Baru. Jakarta: Universitas Indonesia Press.

15. Muladi. (2005). Hak Asasi Manusia, Politik dan Sistem peradilan Pidana. Semarang: Badan Penerbit Universitas Diponegoro.

16. Muladi, \& Arief, B. N. (1998). Teori-teori dan Kebijakan Pidana. Bandung: Penerbit Alumni.

17. Poerdwadarminta, W. (1997). Kamus Bahasa Indonesia.

18. Prodjodikoros, W. (2003). Asas-asas Hukum Pidana di Indonesia. Bandung: Raika Aditama.

19. Rahardjo, S. (2009). Penegakan Hukum Suatu Tinjauan Sosiologis. Yogyakarta: Genta Publishing.

20. Rahardjo, S. (2010). Pemanfaatan ilmu-ilmu social bagi pengembangan hukum. Yogyakarta: Genta Publishing.

21. Rao, S. S. (2009). Engineering Optimazation. New Jersey: John Wiley dan Sons, Inc.

22. Rendro. (2010). Beyond Borders: Communication Modernity \& History The First LSPR Communication Research Conference 2010. London: STIKOM The London School of Public Relations.

23. Salim, \& Nurbani, E. S. (2013). Penerapan Teori hukum Pada Tesis dan Disertasi. Jakarta: Rajawali Press.

24. Sam.S.Sourya. (2005). Ethnic in Criminal Justice (Etika Dalam Peradilan Pidana, Upaya Mencari Kebenaran). Jakarta: PT Cipta Manunggal.

25. Samsudin, A. Q., \& Sumaryo, M. (1985). Kejahatan Anak Suatu Tinjauan Dari Segi Psikologis dan Hukum. Yogyakarta: Liberty.

26. Santoso, T. (2003). Kriminologi. Jakarta: Rajawali Press.

27. Schultz, D. (1990). Psikologi Pertumbuhan. Yogyakarta: Kanisius.

28. Semiawan, C. R. (2010). Metode Penelitian Kualitatif Jenis, Karakteristik dan Keunggulannya. Jakarta: Grafindo.

29. Setiady, T. (2010). Pokok-pokok Hukum Penitensier Indonesia. Bandung: Alfabeta.

30. Soekanto, S. (1985). Efektivitas Hukum dan Peranan Saksi. Bandung: Remaja Karya.

31. Sudarto. (1982). Hukum Pidana dan Perkembangan Masyarakat Kajian Terhadap Pembaharuan Hukum Pidana. Bandung: Sinar Baru.

32. Sudarto. (1983). Hukum dan Hukum Pidana. Bandung: Alumni.

33. Sumaryadi, I. N. (2005). Efektivitas Implementasi Kebijakan Otonomi Daerah. Jakarta: Citra Utama.

34. Syarani, R. (2004). Rangkuman Intisari Ilmu Hukum. Bandung: PT Citra Aditya Bhakti.

35. Widiyanti, N., \& Waskita, Y. (1987). Kejahatan Dalam Masyarakat dan Pencegahannya. Jakarta: Bina Aksara.

36. Agustina, C. (t.thn.). Pemberdayaan Anggota Satuan Perlindungan Masyarakat dalam Penanggulangan Bencana (Studi di Kecamatan Pujon Kabupaten Malang).

37. Fahlefi, Z., Paranoan, D., \& Utomo, H. S. (2014). Penerapan Teknologi Informasi Bagi Pelaksanaan Pelayanan Publik (Studi Kasus pada Badan Pelayanan Perijinan Terpadu Satu Pintu Kota Samarinda. eJournal Administrative Reform, 2014 (4):996-1007.

38. Hasjimzum, Y. (2014). Model Demokrasi dalam Peningkatan Kualitas Pelayanan Publik (Studi Otonomi Daerah dalam Peningkatan Kesejahteraan Masyarakat pasca Reformasi). Jurnal Dinamika Hukum Vol 14 No 3 September 2014.

39. Holle, E. S. (2011). Pelayanan Publik Melalui Electronic Government: Upaya Meminimalisir Praktek maladministrasi dalam Meningkatkan Public Service. Jurnal Sasi Vol. 17 No. 3 Bulan Juli-September 2011.

40. Ismail, C. (2012). Tantangan Polri dalam pemeliharaan Kamtibmas pada masyarakat Demokrasi. Jurnal Srigunting. 
41. Kamarni, N. (2011). Analisis Pelayanan Publik terhadap Masyarakat (Kasus Pelayanan Kesehatan di Kabupaten Agam). Jurnal Manajemen dan Kewirausahaan Volume 2 Nomor 3 September 2011 ISSN: 2086-5031.

42. Muditha, C. R. (t.thn.). Efektifitas Pembinaan Anak Didik Pemasyarakatan dalam upaya perlindungan anak di Lembaga Pemasyarakatan.

43. Ratnasari, D. D., Saleh, C., \& Rozikin, M. (2012). Optimalisasi Peran Koperasi Wanita dalam Meningkatkan Kesejahteraan Anggota (Studi pada Koperasi Wanita Potre Koneng Kabupaten Sumenep). Jurnal Administrasi Publik (JAP), Vol 1, No. 3, 51-60.

44. Reksodiputro, M. (1998). Penanggulangan Masalah Preman dari Pendekatan Kriminologi (Suatu Tanggapan). Jurnal Hukum Pidana dan Kriminologi, volume I, no. 1.

45. Rudianto, Y. (2005). Pelayanan Publik Pada Penyelenggaraan Pemerintah Kecamatan. Jurnal Madani Edisi II/Nopember 2005.

46. Electronic Source: http://aizawaangela020791.blogspot.com/2011/01/ 